\title{
Analisis Kompetensi Profesional Guru
}

\author{
Dewi Yulmasita Bagou', Arifin Suking ${ }^{2}$ \\ 1,2Jurusan Manajemen Pendidikan Fakultas Ilmu Pendidikan Universitas Negeri Gorontalo \\ E-mail: dewi.yulmasita@gmail.com
}

\section{INFO ARTIKEL}

\section{Sejarah Artikel:}

Diterima: Agustus 2020

Disetujui: September 2020

Dipublikasi: September 2020

\section{Kata kunci:}

Kompetensi; Profesional; Guru.

Keywords:

Competence; Professional; Teacher.

\begin{abstract}
ABSTRAK
Penelitian ini bertujuan untuk untuk memperoleh gambaran tentang Analisis Kompetensi Profesional Guru SMA Negeri 2 Gorontalo di Kota Gorontalo . Metode yang digunakan yaitu pendekatan kuantitatif dengan jenis deskriptif. Teknik pengumpulan data menggunakan angket. Teknik analisis data menggunakan analisis deskriptif dalam bentuk tabel frekuensi. Hasil penelitian ini menyatakan bahwa : (1) penguasaan materi, struktur, konsep dan pola pikir keilmuan yang mendukung mata pelajaran yang diampu oleh guru berada pada kategori amat baik, (2) penguasaan standar kompetensi dan kompetensi dasar pada mata pelajaran yang diampu oleh guru berada pada kategori amat baik, (3) pengembangan materi pembelajaran yang diampu secara kreatif oleh guru berada pada kategori baik, (4) pengembangan keprofesian secara berkelanjutan oleh guru berada pada kategori baik, dan (5) pemanfaatan TIK untuk pengembangan diri oleh guru SMA Negeri 2 Gorontalo berada pada kategori baik.
\end{abstract}

\begin{abstract}
This study aims to obtain an overview of the Analysis of Professional Competence of Teachers of SMA Negeri 2 Gorontalo in Gorontalo City. The method used is a quantitative approach with a descriptive type. Data collection techniques using a questionnaire. Data analysis techniques used descriptive analysis in the form of frequency tables. The results of this study state that: (1) mastery of material, structure, concepts and scientific mindset that supports subjects taught by teachers is in the very good category, (2) mastery of competency standards and basic competencies in subjects taught by teachers are in the very good category, (3) the development of learning materials that are creatively taught by the teacher is in the good category, (4) the continuing professional development by the teacher is in the good category, and (5) the use of ICT for self-development by SMA Negeri 2 teachers Gorontalo is in the good category.
\end{abstract}

(C) 2020 Dewi Yulmasita Bagou, Arifin Suking Under The License CC-BY SA 4.0

\section{PENDAHULUAN}

Kompetensi guru merupakan salah satu faktor yang mempengaruhi tercapainya tujuan pembelajaran dan pendidikan di sekolah.Kompetensi guru dapat dinilai penting sebagai alat seleksi dalam penerimaan calon guru, juga dapat dijadikan sebagai pedoman dalam rangka pembinaan dan pengembangan tenaga guru.Pada dasarnya peningkatan kualitas diri seseorang harus menjadi tanggung jawab diri pribadi. Oleh karenanya usaha peningkatan 
kualitas guru terletak pada diri guru itu sendiri. Untuk itu diperlukan adanya kesadaran diri guru untuk senantiasa meningkatkan pengetahuan dan kemampuan yang diperlukan guna peningkatan kualitas kerja sebagai tenaga professional (Zamroni, 2000: 55).

Meskipun banyak para ahli dan hasil penelitian yang menyimpulkan bahwa begitu pentingnya kemampuan guru atau kompetensi yang harus dikuasai guru dalam upaya meningkatkan proses belajar mengajar, namun kenyataan di lapangan masih banyak kita jumpai guru yang kurang kompeten dalam melaksanakan tugasnya. Misalnya di SMA Negeri 2 Gorontalo, ada beberapa guru yang mengajar mata pelajaran yang tidak sesuai dengan jurusan pendidikannya dan belum menguasai teknologi informasi dan komunikasi.Sebagai unsur pokok dalam lembaga pendidikan, guru sebagai pengajar diharapkan memiliki kompetensi sesuai dengan bidang ajarnya. Hal ini setidaknya berimplikasi pada kemudahan dalam mentransfer pengetahuan kepada peserta didik. Untuk mendukung kedudukan seorang guru sebagai tenaga profesional, maka guru harus memiliki dan menguasai standar kompetensi profesional guru. (Atmuji dan Suking, 2015:6) mengemukakan bahwa "kompetensi profesional guru adalah kemampuan, keterampilan, dan perilaku yang harus dimiliki, dihayati dan dikuasai oleh seorang guru yang berhubungan dalam menjalankan tugas keguruan sebagai pengajar yang memerlukan keahlian, kemahiran, atau kecakapan yang memenuhi standar mutu tertentu. (Haryanti, 2010: 33) juga mengemukakan bahwa "kompetensi profesional guru adalah kemampuan keterampilan personal, keilmuan, teknologi, sosial, dan spiritual yang secara kaffah membentuk kompetensi standar profesi guru untuk melaksanakan fungsi dan tugasnya secara maksimal karena memiliki pengalaman yang kaya dibidangnya yang ditandai oleh kompetensi yang menjadi syarat. Sebagai pendidik profesional, maka guru wajib memiliki kompetensi.

Dalam Permendiknas RI No. 16 Tahun 2007 tentang standar kompetensi guru menyebutkan bahwa "kompetensi profesional guru yaitu: (1) menguasai materi, struktur, konsep, dan pola pikir keilmuan yang mendukung mata pelajaran yang diampu, (2) menguasai standar kompetensi dan kompetensi dasar mata pelajaran yang diampu, (3) mengembangkan materi pembelajaran yang diampu secara kreatif, (4) mengembangkan keprofesian secara berkelanjutan dengan melakukan tindakan reflektif, dan (5) memanfaatkan teknologi informasi dan komunikasi untuk mengembangkan diri”.

Adanya tuntutan yang harus dikuasai oleh guru dalam meningkatkan kompetensinya menjadi alasan utama pentingnya penguasaan kompetensi profesional guru. Melalui penguasaan standar kompetensi profesional guru diharapkan mampu meningkatkan 
keprofesionalannya, kualitas belajar peserta didik, dan mutu pendidikan di sekolah khususnya di SMA Negeri 2 Gorontalo.

(Kunandar, 2007), juga mengemukakan bahwa "guru profesional adalah guru yang mengenal tentang dirinya. dirinya adalah pribadi yang dipanggil untuk mendampingi peserta didik untuk/dalam belajar. Guru dituntut untuk mencari tahu terus menerus bagaimana seharusnya peserta didik itu belajar. Maka apabila ada kegagalan peserta didik, guru terpanggil untuk menemukan penyebabnya dan mencari jalan keluar bersama peserta didik bukan mendiamkannya atau malahan menyalahkannya. Sikap yang harus senantiasa dipupuk adalah kesediaan untuk mengenal dirinya dan hendak untuk memurnikan keguruannya. Mau belajar untuk meluangkan waktu untuk menjadi guru. Seorang guru yang tidak bersedia belajar, tidak mugkin kerasan dan bangga menjadi guru. Kerasan dan kebanggaan atas keguruannya adalah langkah untuk menjadi guru yang profesional. Sebagai pendidik profesional, maka guru wajib memiliki kompetensi. Guru dengan kualitas sumber daya manusia yang tinggi dan memiliki kompetensi profesional keguruan berperan sebagai salah satu faktor penentu kualitas mutu pendidikan disamping factor lain yang sama pentingnya (Susilo,dkk, 2010: 118).

Berdasarkan uraian di atas, maka masalah dalam kajianpenelitian ini adalah : bagaimana (1) penguasaan materi, struktur konsep dan pola pikir keilmuan yang mendukung mata pelajaran yang diampu, (2) penguasaan standar kompetensi dan kompetensi dasar mata pelajaran yang diampu, (3) pengembangan materi pelajaran secara kreatif, (4) pengembangan keprofesian secara berkelanjutan, dan (5) pemanfaatan teknologi informasi dan komunikasi.

\section{METODE PENELITIAN}

Penelitian ini menggunakan pendekatan kuantitatif dan jenis penelitian ini bersifat deskriptif,dengan indikator: (1) penguasaan materi, struktur, konsep dan pola pikir keilmuan yang mendukung mata pelajaran yang diampu. (2) penguasaan standar kompetensi dan kompetensi dasar mata pelajaran yang diampu. (3) pengembangan materi pelajaran secara kreatif (4) pengembangan keprofesian secara berkelanjutan, dan (5) pemanfataan teknologi informasi dan komunikasi untuk pengembangan diri. Subyek penelitian adalah seluruh guru di SMA Negeri 2 Gorontalo yang berjumlah 60 orang. Tehnik pegumpulan data menggunakan kusioner (angket). Tehnik analisis data dalam penelitian ini menggunakan analisis deskriptif dalam bentuk tabel frekuensi. 


\section{HASIL PENELITIAN}

Sesuai dengan tujuan untuk memperoleh gambaran tentang Analisis Kompetensi Profesional Guru SMA Negeri 2 Gorontalo di Kota Gorontalo, akan diuraikan deskriptif hasil penelitian melalui angket yang sudah terkumpul yang disebarkan pada 60 responden dengan subyek penelitian yaitu seluruh guru yang ada di SMA Negeri 2 Gorontalo.Berikut diagram hasil analisis kompetensi professional guru SMA Negeri 2 Gorontalo.

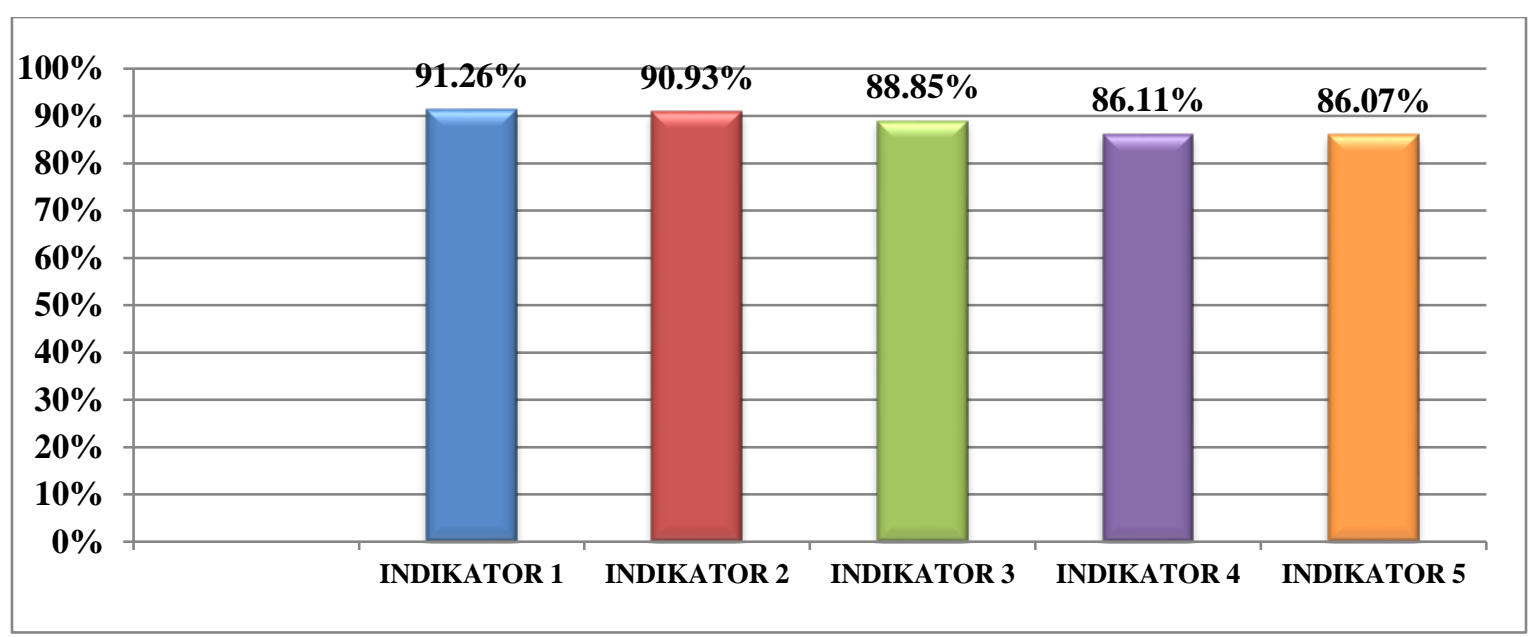

Diagram 1. Hasil analisis kompetensi profesional guru

Hasil analisis kompetensi profesional guru SMA Negeri 2 Gorotalo meliputi : penguasaan materi, struktur, konsep dan pola pikir keilmuan yang mendukung mata pelajaran yang diampu memiliki persentase $91,26 \%$ yang berada pada kategori amat baik, penguasaan standar kompetensi dan kompetensi dasar mata pelajaran yang diampu memiliki persentase 90,93\% yang berada pada kategori amat baik, pengembangan materi pelajaran yang diampu secara kreatif memiliki persentase $88,85 \%$ yang berada pada kategori baik, pengembangan keprofesian secara berkelanjutan memiliki persentase $86,11 \%$ yang berada pada kategori baik, dan pemanfaatan teknologi informasi dan komunikasi untuk pengembangan diri memiliki persentase $86,07 \%$ yang berada pada kategori baik.

\section{PEMBAHASAN}

Hasil penelitian tentang analisis kompetensi profesional guru dapat dilihat dari 5 indikator yaitu : (1) penguasaan materi, struktur, konsep, dan pola pikir keilmuan yang mendukung mata pelajaran yang diampu, (2) penguasaan standar kompetensi dan kompetensi dasar mata pelajaran yang diampu, (3) pengembangan materi pelajaran yang diampu secara kreatif, (4) pengembangan keprofesian secara berkelanjutan, dan (5) pemanfaatan teknologi informasi dan komunikasi untuk pegembangan diri. 
Penguasaan materi, struktur, /konsep dan pola keilmuan yang mendukung mata pelajaran yang diampu oleh guru memperoleh persentase yaitu 91,26\% dengan kategoriamat baik. Hal ini menunjukan bahwa penguasaan materi, konsep dan pola pikir keilmuan yang mendukung mata pelajaran yang diampu oleh guru sangat baik dan perlu ditingkatkan lagi agar bisa kompetensinya bisa mencapai 100\%. Karena (Wina Sanjaya, 2007) mengatakan bahwa kemampuan dalam penguasaan materi pelajaran sesuai dengan bidang studi yang diajarkan adalah salah satu tingkat keprofesionalan seorang guru. Kemampuan penguasaan materi memungkinkannya membimbing peserta didik memenuhi standar kompetensi. Kehadiran seorang guru haruslah seorang yang memang profesional dalam arti memiliki ketrampilan dasar mengajar yang baik, memahami atau menguasai bahan dan memilliki loyalitas terhadap tugasnya sebagai guru. Dengan demikian guru dituntut harus memiliki kompetensi. Salah satu kompetensi yang harus dimiliki seorang guru adalah kompetensi professional. Kompetensi professional yang dimaksud disini adalah kemampuan penguasaan materi pembelajaran secara luas dan mendalam yang memungkinkannya membimbing para peserta didik.

Penguasaan standar kompetensi dan kompetensi dasar mata pelajaran oleh guru memperoleh persentase yaitu $90.93 \%$ dengan kategoriamat baik. Hal ini menunjukan bahwa penguasaan standar kompetensi dan kompetensi dasar mata pelajaran guru sudah memenuhi standar kompetensi profesional. Akan tetapi, masih perlu ditingkatkan lagi agar penguasaan standar kompetensi dan kompetensi dasar guru bisa mencapai 100\%. Karena, penguasaan standar kompetensi dan kompetensi dasar mata pelajaran oleh guru sangatlah penting. Hal ini sependapat dengan (Sanjaya, 2008) yang menyatakan bahwa standar kompetensi harus dikuasai oleh guru agar memudahkan bagi guru tersebut dalam menentukan materi ajar, alokasi waktu, metode pengajaran, sumber belajar, dan penilaian hasil belajar yang nantinya akan tertuang dalam silabus dan rencana pembelajaran. Kompetensi Dasar adalah pengetahuan, keterampilan dan sikap minimal yang harus dicapai oleh siswa untuk menunjukkan bahwa siswa telah menguasai standar kompetensi yang telah ditetapkan, oleh karena itulah maka kompetensi dasar merupakan penjabaran dari standar kompetensi. oleh karena itulah maka kompetensi dasar merupakan penjabaran dari standar kompetensi.Pentingnya penguasaan standar kompetensi dan kompetensi dasar mata pelajaran oleh seorang guru. Hal ini menunjukan bahwa penguasaan standar kompetensi dan kompetensi dasar menjadi acuan dalam menyusun rencana pembelajaran mulai dari tahapan pemilihan materi, penentuan metode, strategi atau media yang cocok digunakan pada materi 
tersebut, sampai pada tahap evaluasi pembelajaran. hal ini berfungsi agar proses pembelajaran lebih efektif dan efisien. selain itu juga, penguasaan standar kompetensi dan kompetensi dasar mata pelajaran merupakan ruang lingkup dari kompetensi profesional guru. Untuk itu, penguasaan standar kompetensi dan kompetensi dasar mata pelajaran perlu ditingkatkan agar bisa menunjang profesionalitas seorang guru dan meningkatkan kualitas belajar peserta didik.

Pengembangan materi pembelajaran yang diampu secara kreatif oleh guru memperoleh persentase yaitu $88,85 \%$ dengan kategori baik. Hal ini menunjukan bahwa kompetensi profesional guru dalam mengembangkan materi pembelajaran yang diampu secara kreatif masih perlu ditingkatkan agar bisa lebih kreatif lagi dalam menyusun atau mengembangkan materi pembelajaran.Mengembangkan materi pelajaran yang diampu secara kreatif merupakan salah satu upaya untuk meningkatkan kompetensi profesional guru. Untuk menjadi seorang guru yang profesional, guru dituntuk kreatifitasnya dalam mengembangkan atau menciptakan suatu pembelajaran yang inovatif yang tentunya bertujuan untuk meningkatkan kualitas dan prestasi peserta didik. Hal ini sependapat dengan Ditendik (2008) yang menyebutkan bahwa, "pembelajaran yang menarik, efektif, dan efisien tentunya membutuhkan bahan ajar yang inovatif. Untuk itu seorang guru yang profesional dituntut kreatifitasnya untuk mampu menyusun bahan ajar yang inovatif, variatif, menarik, kontekstual, dan sesuai dengan kebutuhan peserta didik". Sebagai sekolah yang dianggap maju, gurunya tentu dituntut untuk lebih kreatif dan inovatif dalam pembelajarannya.

Pengembangan keprofesian secara berkelanjutan oleh guru memperoleh persentase yaitu $86,11 \%$ dengan kategori baik. Hal ini menunjukan bahwa pengembangan keprofesian secara berkelanjutan guru masih perlu ditingkatkan lagi agar bisa lebih baik. Hal ini sependapat dengan(Sujianto, 2013) yang menyatakan bahwa PKB adalah pengembangan keprofesian berkelanjutan yang dilaksanakan sesuai dengan kebutuhan guru untuk mencapai standar kompetensi profesi dan/atau meningkatkan kompetensinya di atas standar kompetensi profesinya yang sekaligus berimplikasi kepada perolehan angka kredit untuk kenaikan pangkat/jabatan fungsional guru.Selain itu juga dalam Permenpan dan RB No. 16 Tahun 2009 tentang jabatan fugsional guru dan angka kreditnya pasal 1 ayat 5 menyebutkan bahwa "pengembangan keprofesian berkelanjutan adalah pengembangan kompetensi guru yang dilaksanakan sesuai dengan kebutuhan, bertahap, berkelanjutan untuk meningkatkan profesionalitasnya". Selanjutnya pada Pasal 11 menyebutkan bahwa pengembangan keprofesian berkelanjutan meliputi: pengembangan diri, publikasi ilmiah dan karya 
inovatif.(Luneta, 2012) dalam (Windrawanto, 2015: 94), mengatakan bahwa tujuan pengembangan keprofesian berkelanjutan yaitu: (1) untuk memperbaiki ketrampilan unjuk kerja individu guru atau kelompok tenaga kependidikan melalui pendekatan yang konstruktivistik. Guru dituntut dan diperlakukan sebagai pembelajar aktif, yang dilibatkan dalam tugas-tugas konkret yaitu pengajaran, penilaian, observasi, (2) untuk meningkatkan unjuk kerja individual guru dalam rangka pengembangan karir dan promosi jabatan, (3) untuk mengembangkan pengetahuan profesional dan pemahaman individual guru. Guru disadarkan hakekatnya sebagai praktisi yang reflektif, yang memasuki profesi dengan pengetahuan tertentu, namun memperoleh pengetahuan dan pengalaman baru dibandingkan pengetahuan yang telah dimilikinya, dan (4) untuk memberikan kesempatan kepada guru berpartisipasi dan mempersiapkan diri mengalami perubahan. Hal ini dapat diperoleh dengan guru belajar terus menerus dan pengembangan diri dilakukan dalam proses yang panjang.

Pemanfaatan teknologi informasi dan komunikasi untuk mengembangkan diri oleh guru memperoleh persentase yaitu $86.07 \%$ dengan kategori baik. Hal ini menunjukan bahwa guru masih kurang dalam memanfaatkan teknologi informasi dan komunikasi untuk mengembangkan diri. Oleh karena itu, pemanfaatan teknologi informasi dan komunikasi untuk pengembangan diri guru masih perlu ditingkatkan lagi guna untuk meningkatkan kompetensi profesional guru. Hal ini sependapat dengan (Aka, 2017), yang menyatakan bahwamenguasai teknologi informasi dan komunikasi menjadi tuntutan kompetensi seorang guru saat ini guna mendukung pelaksanaan tugasnya, sehingga setiap guru harus siap untuk terus belajar TIK guna pemenuhan tuntutan kompetensi tersebut. Di era globalisasi kini, sudah tidak zaman lagi para tenaga didik atau guru gagap terhadap teknologi. Teknologi diharapkan menjadi kesatuan dalam pembelajaran sehingga tercipta peserta didik yang lebih aktif dan mandiri. Guru perlu menguasai pemanfaatan TIK untuk kebutuhan belajarnya dan kebutuhan tugasnya sebagai pembelajar. Untuk mengoptimalkan pemanfaatan teknologi informasi dan komunikasi, seorang guru perlu memiliki kompetensi-kompetensi tertentu. Kompetensi yang dimiliki oleh setiap guru akan menunjukan kualitas guru yang sebenarnya. Kompetensi berwujud dalam bentuk penguasaan pengetahuan, keterampilan, maupun sikap professional. Dengan kata lain seorang guru akan dikatakan kompeten atau menguasai kompetensi penguasaan TIK jika menguasai standar kompetensi penguasaan TIK. 
Jambura Journal of Educational Management

Volume 1 Nomor 2, September 2020, Halaman 122-130

ISSN-Online: 2721-2106

\section{SIMPULAN}

Berdasarkan hasil penelitian yang dilakukandi SMA Negeri 2 Gorontalo diperoleh kesimpulan bahwa penguasaan materi, struktur, konsep, dan pola pikir keilmuan yang mendukung mata pelajaran yang diampu sudah memenuhi standar kompetensi yang telah ditetapkan,penguasaan standar kompetensi dan kompetensi dasar mata pelajaran yang diampu sudah memenuhi standar kompetensi yang telah ditetapkan, pengembangan materi pelajaran yang diampu secara kreatif sudah memenuhi standar kompetensi yang telah ditetapkan,pengembangan keprofesian secara berkelanjutan sudah memenuhi standar kompetensi yang telah ditetapkan dan pemanfaatan teknologi informasi dan komunikasi untuk mengembangkan diri sudah memenuhi standar kompetensi yang telah ditetapkan.

\section{REFERENSI}

Aka, Kukuh, A. 2017. Pemanfaatan eknologi Informasi dan Komunikasi (TIK) Sebagai Wujud Inovasi Sumber Belajar Di Sekolah Dasar. Kediri: Universitas Nusantara PGRI. FKIP. PGSD. Jurnal Pendidikan dan Pembelajaran Sekolah Dasar. Volume 1 Nomor 2.http://journal.umsurabaya.ac.id/index.php/pgsd/article/viewFile/1041/724 Di akses: Tanggal 23 Maret 2019

Atmuji, Setyo Dan Suking, A. 2015. Pengaruh Kecerdasan Sosial, Kompetensi Profesional Dan Perilaku Guru Dalam Mengajar Terhadap Efektivitas Pembelajaran Pada Sma Negeri Di Kecamatan Luwuk Kabupaten Banggai. Universitas Negeri Gorontalo.Http://Ejournal.Ung.Ac.Id/Index.Php/JK/Article /1345/Pdf.Diakses: 06 November 2018.

Departemen Pendidikan Nasional. 2007. Peraturan Menteri Pendidikan Nasional Nomor 16 Tahun 2007 Tentang Standar Kualifikasi Akademik Dan Kompetensi Guru. BSNP. Jakarta: Depdiknas.

Direktorat Tenaga Kependidikan Direktorat Jenderal Peningkatan Mutu Pendidik dan Tenaga Kependidikan Departemen Pendidikan Nasional. 2008. Media Pembelajaran dan Sumber Belajar. Jakarta:Materi Diklat Calon Pengawas Sekolah/Pengawas Sekolah.

Haryanti, Titik. 2010. Pengaruh Kompetensi Profesional Guru Terhadap Minat Belajar Pada Mata Pelajaran Fiqih Pada Siswa Kelas VIII Mts Yasu'a Pilangwetan, Kec. Kebonagung, Kab. Demak, Tahun Ajaran 2009-2010. Salatiga: Jurusan Tarbiyah, Program Studi Pendidikan Agama Islam, Sekolah Tinggi Agama Islam Negeri (STAIN).http://jurnaliainpontianak.or.id/index.php/jp2d/article/view/1208.

Di akses: Tanggal 24 Januari 2019

Kunandar. 2007. Guru Profesional "Implementasi Kurikulum Tingkat Satuan Penddikan (KTSP) Dan Persiapan Menghadapi Sertifikasi”. Jakarta: PT. Raja Grafindo Persada. 
Peraturan Menteri Negara Pendayagunaan Aparatur Negara dan Reformasi Birokrasi Nomor 16 Tahun 2009 tentang Jabatan Fungsional Guru Dan Angka Kreditnya

Sanjaya, Wina. 2008. Strategi Pembelajaran Berorientasi Standar Proses Pendidikan. Jakarta: Kencana.

Sanjaya, Wina. 2007. kurikulum dan pembelajaran. Jakarta: kencana prenada media group.

Saud, Udin, S. 2009. Pengembangan Profesi Guru. Bandung: Alfabeta

Sujianto. 2013. Pengembangan Profesionalitas Berkelanjutan/Continuing Professionality Development (CPD) Guru Bersertifikat Pendidik Di SMK Rumpun Teknologi SeMalang Raya. Pendidikan Kejuruan. Pascasarjana Universitas Negeri MalangHttps:// Media.Neliti.Com/Media/Publications/122481-ID-None.Diakses: 13 Februari 2019

Susilo, M. Joko, dkk. 2010. Pemberdayaan Guru. Yogyakarta: Pustaka Pelajar.

Windrawanto, Yustinus. 2015. Pelatihan Dalam Rangka Pengembangan Keprofesian Berkelanjutan Guru: Suatu Tinjauan Literatur.Program Studi Bimbingan dan Konseling. FKIP. Universitas Kristen Satya Wacana. Vol. 31, No.2. Desember 2015: 90-101. http://ejournal.uksw.edu/satyawidya/article/download/621/414/.Diakses: 30 Mei 2019.

Zamroni. 2000. Paradigma Pendidikan Masa Depan. Yogyakarta: BIGRAF Publishing. 